\title{
Sexual Dimorphism in Passive Avoidance Behavior of Rats: Relation to Body Weight, Age, Shock Intensity and Retention Interval
}

\author{
FILIPPO DRAGO, BÉLA BOHUS, ${ }^{1}$ UMBERTO SCAPAGNINI AND DAVID DE WIED \\ Rudolf Magnus Institute for Pharmacology, Medical Faculty, University of Utrecht, Vondellaan 6, Utrecht, \\ The Netherlands \\ and \\ Department of Pharmacology, University of Catania, \\ Catania, Italy
}

Received 3 July 1979

\begin{abstract}
DRAGO, F., B. BOHUS, U. SCAPAGNINI AND D. DE WIED. Sexual dimorphism in passive avoidance behavior of rats: Relation to body weight, age, shock intensity and retention interval. PHYSIOL. BEHAV. 24(6) 1161-1164, 1980.Female rats were inferior to age- and weight-matched males in the retention of a step-through type passive avoidance response 24 and $48 \mathrm{hr}$ after the learning. This sex difference could be observed at different intensities of foot shock which was used as aversive stimulus during the single learning trial. Additionally, unlike in males, retention of the passive avoidance response in the females was not the function of shock intensity. Male and female rats, however, showed similar passive avoidance if tested immediately after the learning trial. The results suggest the existence of sexual dimorphism in memory processes.
\end{abstract}

Passive avoidance Sexual dimorphism Body weight Age Shock intensity Retention interval

SEXUAL dimorphism in sexually unrelated behaviors has been often observed in rodents. In active avoidance situatoins, female rats acquire the response quicker and are more resistant to extinction than males $[3,4,7,9,11,14]$. In contrast, passive avoidance behavior of female rats is inferior to that of males $[5,9,17]$. Passive avoidance retention of male rats is a function of shock intensity, shock duration and the learning-retention interval [1]. Reactivity to electric foot shock also is related to the sex $[3,8,12,15]$, body weight and age [16]. Since differences in reactivity to foot shock, which is used as aversive stimulus at the learning, may influence later retention of a passive avoidance response, the present experiments were designed to investigate sexual dimorphism in the retention of a passive avoidance response in relation to body weight, age, shock intensity and learning-retention interval.

METHOD

\section{Animals}

A total of 54 female and 78 male SPF Wistar rats $(\mathrm{Cpb}$. TNO, Zeist, The Netherlands) were used. The rats were housed in groups of 3 during the experiments and were supplied with ad lib standard laboratory food and water. The light was on between 5:00 a.m. and 19:00 p.m. and the behavioral tests occurred between 14:00 and 18:00 p.m.

\section{Apparatus}

Passive avoidance behavior was studied in a step-through type apparatus as described by Ader et al. [1]. Briefly, a mesh-covered elevated runway was attached to the front centre of a large compartment measuring $50 \times 50 \times 50 \mathrm{~cm}$. It was constructed of black Plexiglas and equipped with grid floor. The opening between the runway and the large compartment was separated by a guillotine door. A $25 \mathrm{~W}$ lamp illuminated the runway and the large compartment remained dark. The experiments were performed in a soundattenuated chamber which was dark except for the illumination of the runway.

\section{Procedure}

On Day 1 the rats were adapted to the large dark compartment for $2 \mathrm{~min}$ with the guillotine door closed. This was immediately followed by a trial in which the rat was placed on the runway facing away from the dark compartment and allowed to enter the dark. Three more approach trials were given on Day 2 with an intertrial interval of minimally $5 \mathrm{~min}$. The rats were kept in the dark compartment for $10 \mathrm{sec}$ upon lowering the guillotine door. The last of these trials was followed by a single $2 \mathrm{sec}$ unavoidable scrambled foot shock immediately after entering the dark compartment. The intensity of shock was $0.5 \mathrm{~mA}, \mathrm{AC}$, unless otherwise stated.

'To whom all reprint requests should be addressed. 
The retention of the passive avoidance response was tested 24 and $48 \mathrm{hr}$ after the learning trial. The subject was placed on the elevated runway and the latency to re-enter the dark compartment was recorded up to a maximum of $300 \mathrm{sec}$. In one experiment retention was tested in separate groups of rats 1,30 or $180 \mathrm{~min}$ after the learning trial.

\section{Statistical Procedures}

Nonparametric statistics of Mann-Whitney and Kruskal-Wallis were used to calculate the significance of differences.

\section{RESULTS}

Table 1 summarizes the observations on passive avoidance behavior of two weight- and one age-matched groups of female and male rats. The latencies to approach the dark compartment prior to the learning trial were somewhat longer in all males than in females. The differences however were not significant. Passive avoidance latencies of all male groups were always significantly longer than in females both at the 24 and $48 \mathrm{hr}$ retention tests when the shock intensity was $0.50 \mathrm{~mA}$ for $2 \mathrm{sec}$ during the learning trial. Avoidance latencies were not different within the different groups of female and male rats.

Table 2 depicts the passive avoidance retention behavior of female rats and their weight- and age-matched male counterparts when different shock intensities were used at the single learning trial. The approach latencies, like in the former experiment, did not differ significantly. These data are therefore omitted from the Table. The latencies to reenter the dark compartment were always shorter in females than in the weight- or age-matched male rats. The differences were significant except of the groups receiving foot shock with the intensity of $0.25 \mathrm{~mA}$. An analysis of the data in relation to the intensity of foot shock indicated that passive avoidance latencies of both weight- and age-matched male rats significantly depended on the shock intensity $(p<0.05$; Kruskal-Wallis test). The higher the shock intensity was, the longer avoidance latencies were observed. A similar relation to shock intensity was absent in the females. Median avoidance latencies were almost indistinquisable at the shock intensities of $0.25,0.50$ and $0.75 \mathrm{~mA}$. A significant difference was however found between the 0.25 and $1.0 \mathrm{~mA}$ groups but at the $24 \mathrm{hr}$ retention test $(p=0.05$; MannWhitney test).

Table 3 shows that, comparably to age-matched males, female rats displayed maximal passive avoidance $(300 \mathrm{sec})$ when tested 1 min after the learning trial. However, significantly shorter avoidance latencies were observed in the females when the learning-retention interval was 30 or 180 $\min$.

\section{DISCUSSION}

The present observations suggest that mature female rats display poorer passive avoidance behavior in a step-through type situation than male rats. This sexual dimorphism is independent of factors such as body weight, age (at least within the limit of this study) and the intensity of foot shock which was used as aversive stimulus during the single learning trial. Accordingly, weight- and age-dependent differences in reactivity to foot shock [16] cannot explain the sexual dimorphism in passive avoidance behavior. Our observations however pointed to the importance of the learningretention test interval. Female rats showed maximal passive avoidance retention shortly after the learning similar to males of the same age. This may indicate that learning of the response is not principally different in males and females but sexual dimorphism exist in the retention of the learned response even $30 \mathrm{~min}$ after learning. The inferiority of female rats in this passive avoidance situation is not easily explained by sex dimorphism in activation, inhibition, fear or emotionality (see [2]). Passive avoidance performance may be inversely related to sex. Female rats show superior passive avoidance performance-e.g. suppression ratio-when ongoing operant behavior is suppressed by the presence of aversion stimulation $[10,18]$. Conversely, female rats display inferior passive avoidance behavior when the retention of the response is not measured immediately after the aversive experience $[5,6,9,17]$. The present observations agree with these studies.

One-trial learning passive avoidance paradigms are often used to study memory processes. Consolidation of experi-

TABLE 1

THE EFFECTS OF WEIGHT AND AGE ON THE RETENTION OF A ONE-TRIAL LEARNING PASSIVE AVOIDANCE RESPONSE IN FEMALE AND MALE RATS*

\begin{tabular}{|c|c|c|c|c|c|c|}
\hline \multirow{3}{*}{$\begin{array}{l}\text { Groups } \\
\text { Weight-matched }\end{array}$} & \multirow{3}{*}{$\begin{array}{l}\text { Sex } \\
\begin{array}{l}\text { Female } \\
\text { Male }\end{array}\end{array}$} & \multirow{3}{*}{$\begin{array}{c}\text { Body weight }{ }^{\dagger} \\
141 .(52) \\
157 .(47)\end{array}$} & \multirow{3}{*}{$\begin{array}{c}\text { Approach latency } \ddagger \\
17 . \\
28.5\end{array}$} & \multicolumn{3}{|c|}{$\begin{array}{l}\text { Avoidance latency } \$ \\
24 \mathrm{hr} \\
\quad 48 \mathrm{hr}\end{array}$} \\
\hline & & & & \multirow{2}{*}{$\begin{array}{c}50 . \# \\
269 .\end{array}$} & \multirow{2}{*}{$\begin{array}{l}20.5 \# \\
162 .\end{array}$} & \multirow{2}{*}{$\begin{array}{l}\text { (6) } \\
(6)\end{array}$} \\
\hline & & & & & & \\
\hline & Female & $195 .(84)$ & 22. & 78.\# & $50 . \#$ & (6) \\
\hline & Male & 201. (56) & 26. & 300. & 262. & (6) \\
\hline \multirow[t]{2}{*}{ Age-matched } & Female & 158. $(60)$ & 13. & 59.\# & 72.5 & (6) \\
\hline & Male & 243. (60) & 25.5 & 300. & 300. & (6) \\
\hline
\end{tabular}

*Shock intensity at the learning trial: $0.25 \mathrm{~mA}$ for $2 \mathrm{sec}$.

$\dagger$ Mean in grams.

$\ddagger$ Median total latency of the 2 nd, 3 rd and 4 th approach trials in sec.

$\$$ Median in sec.

IRetention test 24 respectively $48 \mathrm{hr}$ after the learning trial.

$\# p<0.01$ (Mann-Whitney test).

The age in days and the number of rats in brackets. 
TABLE 2

THE EFFECT OF SHOCK INTENSITY ON THE RETENTION OF A PASSIVE AVOIDANCE RESPONSE IN FEMALE AND WEIGHT- OR AGE-MATCHED MALE RATS

\begin{tabular}{|c|c|c|c|c|c|c|}
\hline Shock intensity & Sex & Group & Body weight* & $\begin{array}{l}\text { Avoida } \\
24 \mathrm{hr}\end{array}$ & $\begin{array}{l}\text { tencytt } \\
48 \mathrm{hr}\end{array}$ & \\
\hline $0.25 \mathrm{~mA}$ & $\begin{array}{l}\text { Female } \\
\text { Male }\end{array}$ & $\begin{array}{l}\text { Weight-m. } \\
\text { Age-m. }\end{array}$ & $\begin{array}{l}158 .(60) \\
163 .(49) \\
254 .(65)\end{array}$ & $\begin{array}{l}27.5 \\
85 . \\
53 .\end{array}$ & $\begin{array}{l}13.5 \\
36 . \\
58.0\end{array}$ & $\begin{array}{l}(6) \\
(6) \\
(6)\end{array}$ \\
\hline $0.50 \mathrm{~mA}$ & $\begin{array}{l}\text { Female } \\
\text { Male }\end{array}$ & $\begin{array}{l}\text { Weight-m. } \\
\text { Age-m. }\end{array}$ & $\begin{array}{l}158 .(60) \\
157 .(47) \\
254 .(63)\end{array}$ & $\begin{array}{l}59 . \S \\
269 . \\
300 .\end{array}$ & $\begin{array}{l}72.5 \S \\
162 . \\
300 .\end{array}$ & $\begin{array}{l}(6) \\
(6) \\
(6)\end{array}$ \\
\hline $0.75 \mathrm{~mA}$ & $\begin{array}{l}\text { Female } \\
\text { Male }\end{array}$ & $\begin{array}{l}\text { Weight-m. } \\
\text { Age-m. }\end{array}$ & $\begin{array}{l}167 .(63) \\
183 .(52) \\
226 .(59)\end{array}$ & $\begin{array}{l}35.5 \S \\
300 . \\
300 .\end{array}$ & $\begin{array}{l}6 . \S \\
300 . \\
300 .\end{array}$ & $\begin{array}{l}\text { (6) } \\
\text { (6) } \\
(6)\end{array}$ \\
\hline $1.00 \mathrm{~mA}$ & $\begin{array}{l}\text { Female } \\
\text { Male }\end{array}$ & $\begin{array}{l}\text { Weight-m. } \\
\text { Age-m. }\end{array}$ & $\begin{array}{l}145 .(52) \\
164 .(48) \\
198 .(56)\end{array}$ & $\begin{array}{l}160.8 \\
300 . \\
300 .\end{array}$ & $\begin{array}{l}39.8 \\
300 . \\
300 .\end{array}$ & $\begin{array}{l}\text { (6) } \\
\text { (6) } \\
\text { (6) }\end{array}$ \\
\hline
\end{tabular}

\footnotetext{
*Mean in grams

$\dagger$ Median in sec.

$\ddagger$ Retention test 24 respectively $48 \mathrm{hr}$ after the learning trial.

$\$ p<0.01$ (Mann-Whitney test).

qData from Table 1.

The age in days and the number of rats in brackets.
}

TABLE 3

SHORT-TERM RETENTION OF A PASSIVE AVOIDANCE RESPONSE IN FEMALE AND AGE-MATCHED MALE RATS

\begin{tabular}{clccc}
\hline Learning-retention interval $^{*}$ & Sex & Body weight $\dagger$ & Retention latency $\ddagger$ & \\
\hline \multirow{2}{*}{$1 \mathrm{~min}$} & Female & $136 .(51)$ & 300. & $(6)$ \\
& Male & $228 .(60)$ & 300. & $(6)$ \\
\multirow{3}{*}{$30 \mathrm{~min}$} & Female & $131 .(50)$ & 43.8 & $(6)$ \\
& Male & $232 .(58)$ & 300. & $(6)$ \\
\multirow{2}{*}{$180 \mathrm{~min}$} & Female & $142 .(53)$ & $71 . \S$ & $(6)$ \\
& Male & $225 .(59)$ & 300. & $(6)$ \\
\hline
\end{tabular}

*Shock intensity at the learning trial: $0.50 \mathrm{~mA}$ for $2 \mathrm{sec}$.

$\dagger$ Mean in grams.

$\ddagger$ Median in sec.

$\S p<0.05$ (Mann-Whitney test).

Number of rats in brackets.

ence takes place in the first postlearning hours and the storage of information may determine later performance [13]. Female rats were comparable to males immediately after learning but became inferior from $30 \mathrm{~min}$ in. Furthermore, a basic characteristic of passive avoidance behavior-i.e. the relation between the rate of retention and shock intensitywhich is prominent in male rats [1] is absent in females. These observations may indicate that consolidation and/or retrieval processes are sexually dimorphic. This hypothesis may however be premature. Sexual dimorphism in exploratory activity (see for ref. [2]) might have interfered with passive avoidance performance which served as the measure of memory. Therefore, the memory hypothesis and the causes for differences in passive avoidance behavior, in particular as a result of differences in hormonal profils, are further investigated.

\section{REFERENCES}

1. Ader, R., J. A. W. M. Weijnen and P. Moleman. Retention of a passive avoidance response as a function of the intensity and duration of electric shock. Psychon. Sci. 26: 125-128, 1972.

2. Archer, J. Rodent sex differences in emotional and related behavior. Behav. Biol. 14: 451-479, 1975.
3. Beatty, W. W. and P. A. Beatty. Hormonal determinants of sex differences in avoidance behavior and reactivity to electric shock in the rat. J. comp. physiol. Psychol. 73: 446-455, 1970.

4. Beatty, W. W., P. A. Beatty and R. E. Bowman. A sex difference in the extinction of avoidance behavior in rats. Psychon. Sci. 23: 213-214, 1971. 
5. Beatty, W. W., K. C. Gregoire and L. L. Parmiter. Sex differences in the retention of a passive avoidance behavior in rats. Bull. Psychon. Soc. 2: 99-100, 1973.

6. Chambers, K. C. and C. B. Sengstake. Sexually dimorphic extinction of a conditioned taste aversion in rats. Anim. Learn. Behav. 4: 181-185, 1976.

7. Davis, H., J. W. Porter, J. Burton and S. Levine. Sex and strain differences in leverpress shock escape behavior. Physiol. Psychol. 4: 351-356, 1976.

8. Dennis, M. Sex-dependent and sex-independent neural control of reactivity to electric footshock in the rat. Expl Neurol. 37: 256-268, 1972.

9. Denti, A. and A. Epstein. Sex differences in the acquisition of two kinds of avoidance behavior in rats. Physiol. Behav. 8: 611-615, 1972.

10. Leshner, A. I., K. H. Brookshire and C. N. Stewart. The effects of adrenal demedullation on conditioned fear. Hormones Behav. 2: 43-48, 1971.

11. Levine, S. and P. L. Broadhurst. Genetic and ontogenetic determinants of adult behavior in the rat. J. comp. physiol. Psychol. 56: 423-428, 1963.

12. Marks, H. E. and S. H. Hobbs. Changes in stimulus reactivity following gonadectomy in male and female rats of different ages. Physiol. Behav. 8: 1113-1119, 1972.
13. McGaugh, J. L., S. F. Zornetzer, P. E. Gold and P. W. Landfield. Modification of memory systems: some neurobiological aspects. Q. Rev. Biophys. 5: 163-186, 1972.

14. Nakamura, C. Y. and N. H. Anderson. Avoidance behavior differences within and between strains of rats. J. comp. physiol. Psychol. 55: 740-747, 1962.

15. Paré, W. Age, sex, and strain differences in the aversive threshold to grid shock in the rat. J. comp. physiol. Psychol. 69: 214-218, 1969.

16. Paré, W. Interaction of age and shock intensity on acquisition of a discriminated conditioned emotional response. J. comp. physiol. Psychol. 68: 364-369, 1969.

17. Poll, N. E. van de, J. P. C. De Bruin, H. van Dis and H. G. van Oyen. Gonadal hormones and the differentiation of sexual and aggressive behavior and learning in the rat. In: Progress in Brain Research, 48: edited by M. A. Corner, R. E. Baker, N. E. van de Poll, D. F. Swaab and H. B. M. Uylings. Amsterdam, New York, Oxford: Elsevier, 1978, pp. 309-325.

18. Singh, S. D. Conditioned emotional response in the rat: I. Constitutional and situational determinants. J. comp. physiol. Psychol. 52: 574-578, 1959. 